\title{
PENANAMAN NILAI-NILAI KARAKTER DI LEMBAGA PENDIDIKAN ISLAM
}

\author{
Imam Khoirul Ulumuddin \\ FAI UNWAHAS \\ Imamku85@gmail.com
}

\begin{abstract}
ABSTRAK
Penanaman nilai-nilai pendidikan karakter di masing-masing lembaga pendidikan Islam tentunya tidak akan sama, karena lembaga satu dengan lainnya mempunyai visi dan misi yang berbeda, atas dasar visi dan misi itulah pendidikan karakter dibuat. Penelitian ini memfokuskan pada pelaksanaan penanaman nilai-nilai karakter di MA Riyadlus Sholihin Al Islamy Kelurahan Ngijo Kecamatan Gunungpati Kota Semarang dengan menggunakan pendekatan kualitatif fenomenologi. Hasil dari penelitian ini menunjukkan bahwa pelaksanaan penanaman nilai-nilai karakter di MA Riyadlus Sholihin Al Islamy Gunungpati yang notabenenya berada dinaungan Pondok Pesantren, nilai-nilai karakternya tidak jauh dari karakter pondok pesantren itu sendiri, yaitu melalui dzikir Rothib Al Hadad, jama'ah sholat Dhuha dan tartilan alQur'an yang dirangkai dalam kegiatan rutinitas harian sebelum KBM berlangsung.

Kata Kunci: pendidikan karakter, pondok pesantren, lembaga pendidikan Islam
\end{abstract}

\begin{abstract}
Implementation of characteristic values in each Islamic education institute is never similiar, because an institute and others having their own vision and mision. Based on that vision and mision, characteristic education is made. The writer focus on the implementation of characteristic values and its application in MA Riyadlus Sholihin Al Islami, Ngijo, Gunungpati, Semarang using phenomenology kualitatif approach. The result of this study shows that the implementation of characteristic values in MA Riyadlus Sholihin Al Islamy which is its management under Pondok Pesantren, its characteristic values almost
\end{abstract}


the same with its pondok pesantren itself, such as by dzikir Rothib Al Hadad, praying Dhuha together and reciting Al Quran which conduct as daily activity before teaching learning process.

Keywords: characteristic education, pondok pesantren, Islamic education institute

\section{A. PENDAHULUAN}

Persoalan yang muncul di masyarakat seperti korupsi, kekerasan, kejahatan seksual, perusakan, perkelahian massa, kehidupan ekonomi yang konsumtif, kehidupan politik yang tidak produktif, dan sebagainya menjadi topik pembahasan hangat di media massa, seminar, dan di berbagai kesempatan. Berbagai alternatif penyelesaian diajukan seperti peraturan, undang-undang, peningkatan upaya pelaksanaan dan penerapan hukum yang lebih kuat. Alternatif lain yang banyak dikemukakan untuk mengatasi, paling tidak mengurangi, masalah budaya dan karakter bangsa yang dibicarakan itu adalah pendidikan. Pendidikan dianggap sebagai alternatif yang bersifat preventif karena pendidikan membangun generasi baru bangsa yang lebih baik. Sebagai alternatif yang bersifat preventif, pendidikan diharapkan dapat mengembangkan kualitas generasi muda bangsa dalam berbagai aspek yang dapat memperkecil dan mengurangi penyebab berbagai masalah budaya dan karakter bangsa. 1

1 Kemendiknas, Bahan Pelatihan Pengembangan Pendidikan Budaya dan Karakter Bangsa (Jakarta : Badan Penelitian dan Pengembangan Pusat Kurikulum, 2010), hlm. 1. 
Pendidikan karakter sebenarnya bukan hal yang baru. Sejak awal kemerdekaan, masa orde lama, masa orde baru, dan masa reformasi sudah dilakukan dengan nama dan bentuk yang berbeda-beda. Namun hingga saat ini belum menunjukkan hasil yang optimal, terbukti dari fenomena sosial yang menunjukkan perilaku yang tidak berkarakter sebagaimana disebut di atas. Dalam Undang-undang No. 20 tahun 2003 tentang Sistem pendidikan Naional telah ditegaskan bahwa "Pendidikan nasional berfungsi mengembangkan kemampuan dan membentuk watak serta peradaban bangsa yang bermartabat dalam rangka mencerdaskan kehidupan bangsa, bertujuan untuk berkembangnya potensi peserta didik agar menjadi manusia yang beriman dan bertakwa kepada Tuhan Yang Maha Esa, berakhlak mulia, sehat, berilmu, cakap, kreatif, mandiri, dan menjadi warga negara yang demokratis serta bertanggung jawab." Namun tampaknya upaya pendidikan yang dilakukan oleh lembaga pendidikan belum sepenuhnya mengarahkan dan mencurahkan perhatian secara komprehensif pada upaya pencapaian tujuan pendidikan nasional.

Menteri Pendidikan Nasional, pada waktu itu dijabat oleh Mohammad Nuh menegaskan, bahwa "tidak ada yang menolak tentang pentingnya karakter, tetapi yang lebih penting adalah bagaimana menyusun dan menyistemasikan, sehingga anak-anak dapat lebih berkarakter dan lebih berbudaya". Dalam upaya menyusun dan menyistemasikan pendidikan karakter tersebut, maka disusunlah kurikulum pendidikan karakter, yang kita kenal 
dengan sebutan K13 (Kurikulum 2013) yang lebih menekankan kepada aspek afektif atau ranah emosional. Oleh karena itu seluruh lembaga pendidikan baik yang dibawah Kemendikbud lebih-lebih di bawah Kemenag diharapkan bisa menerapkan kurikulum K13 dalam membentuk karakter peserta didik.

\section{B. PENDIDIKAN KARAKTER}

\section{Tinjauan Umum Pendidikan Karakter}

Pendidikan karakter dewasa ini dirasa sangat penting, sehingga pemerintah melalui Kemendikbud terus menggodok Kurikulum 2013 supanya menjadi Kurikulum yang efektif dan efisien dalam membangun karakter peserta didik. Pemerintah melalui pelatihan-pelatihan atau Bimtek, guru-guru dilatih untuk bisa menerapkan Kurikulum dengan baik dan benar sesuai tujuan dari kurikulum tersebut. Kurikulum 2013 yang digagas Kemendikbud pada masa Muh. Nuh itu sekarang bertrasformasi menjadi Kurikulum Nasional atau dikenal denga Kurtilas.

Individu yang berkarakter baik adalah individu yang bisa membuat keputusan dan siap mempertanggungjawabkan setiap akibat dari keputusan yang ia buat. $^{2}$ Pembentukan karakter merupakan salah satu tujuan pendidikan nasional. Pasal I UU SISDIKNAS tahun 2003 menyatakan bahwa diantara tujuan pendidikan nasional adalah mengembangkan potensi peserta

\footnotetext{
2 Jamal Ma'mur Asmani, Buku Panduan Internalisasi Pendidikan Karakterdi
} Sekolah (Jakarta : Grasindo, 2010), hlm. 29. 
adalah mengembangkan potensi peserta didik untuk memiliki kecerdasan, kepribadian, dan akhlak mulia. ${ }^{3}$

2. Ruang Lingkup Pendidikan Karakter

Ruang lingkup pendidikan karakter secara garis besar meliputi dua aspek yang dimiliki manusia, yaitu aspek ke dalam dan aspek keluar. Aspek ke dalam atau aspek potensi meliputi aspek kognitif (olah pikir), afektif (olah hati), dan psikomotorik (olah raga). Aspek ini ada di dalam diri tiap individu secara natural. Sedangkan aspek keluar yaitu aspek manusia dalam konteks sosiokultur dalam interaksinya dengan orang lain yang meliputi interaksi dalam keluarga, sekolah, masyarakat, dan lingkungan. Masing-masing aspek memiliki ruang yang berisi berbagai macam nilai pendidikan karakter. Kedua aspek inilah yang mencoba untuk dikembangkan dalam implementasi pendidikan karakter supaya terbentuk pribadi yang berkarakter, tangguh, dan bertanggung jawab. ${ }^{4}$

\footnotetext{
${ }^{3}$ Ibid.

${ }^{4}$ Kemendiknas, Desain Induk Pendidikan Karakter, (Jakarta: Puskur, 2011), hlm. 9
} 
Penjelasan mengenai ruang lingkup pendidikan karakter di Indonesia terdapat pada bagan berikut ini.

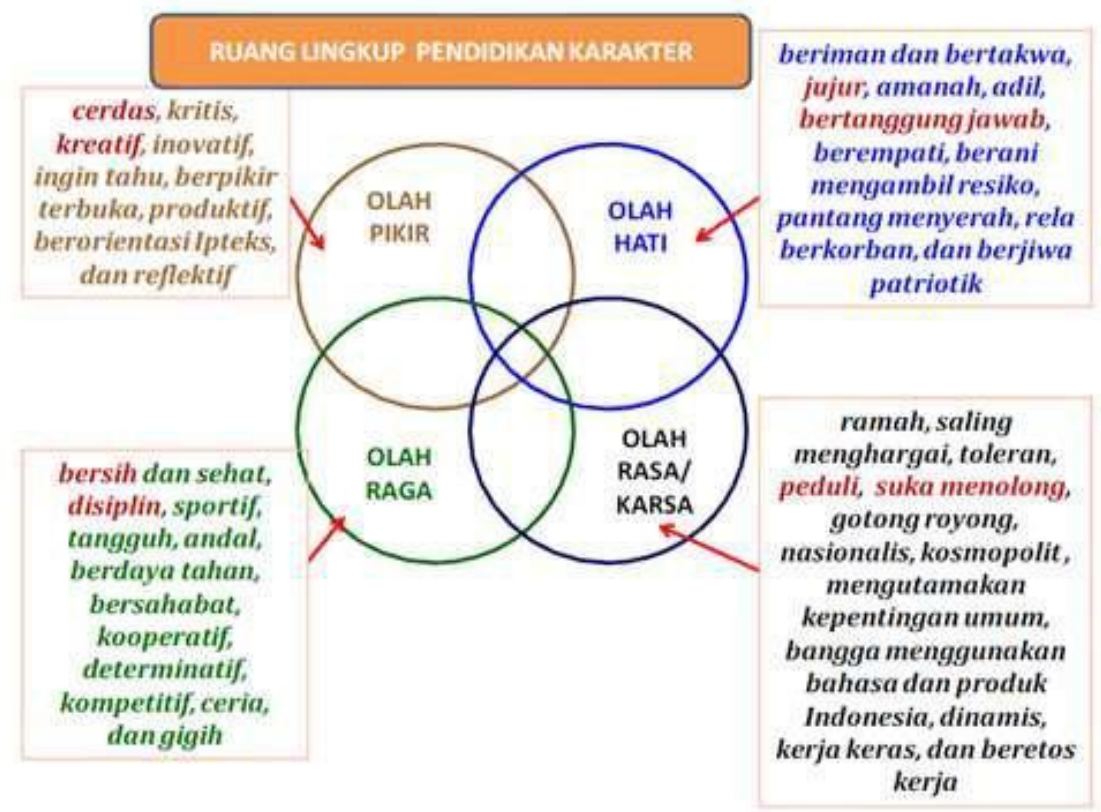

Bagan Ruang Lingkup Pendidikan Karakter (Puskur, 2011:9)

Dalam upaya membentuk kepribadian peserta didik yang sesuai ruang lingkupnya, pengembangan karakter tidak dimasukkan sebagai pokok bahasan tetapi terintegrasi kedalam mata pelajaran, pengembangan diri dan budaya satuan pendidikan. Oleh karena itu pendidik dan satuan pendidikan perlu mengintegrasikan nilai-nilai yang dikembangkan dalam pendidikan karakter ke dalam Kurikulum, silabus yang sudah ada. Prinsip pembelajaran yang digunakan dalam pengembangan pendidikan karakter mengusahakan agar peserta didik mengenal dan menerima nilai-nilai karakter sebagai milik peserta didik 
dan bertanggung jawab atas keputusan yang diambilnya melalui tahapan mengenal pilihan, menilai pilihan, menentukan pendirian, dan selanjutnya menjadikan suatu nilai sesuai dengan keyakinan diri. Dengan prinsip ini peserta didik belajar melalui proses berpikir, bersikap, dan berbuat. Ketiga proses ini dimaksudkan untuk mengembangkan kemampuan peserta didik dalam melakukan kegiatan sosial dan mendorong peserta didik untuk melihat diri sendiri sebagai makhluk sosial. Berikut prinsip-prinsip yang digunakan dalam pengembangan pendidikan karakter.5

\section{a. Berkelanjutan}

Berkelanjutan mengandung makna bahwa proses pengembangan nilai-nilai karakter merupakan sebuah proses panjang dimulai dari awal peserta didik masuk sampai selesai dari suatu satuan pendidikan. Sejatinya, proses tersebut dimulai dari TK/RA berlanjut ke kelas satu SD/MI atau tahun pertama dan berlangsung paling tidak sampai kelas 9 atau kelas terakhir SMP/MTs. Pendidikan karakter di SMA/MA atau SMK/MAK adalah kelanjutan dari proses yang telah terjadi selama 9 tahun. Sedangkan pendidikan karakter di Perguruan Tinggi merupakan penguatan dan pemantapan pendidikan karakter yang telah diperoleh di SMA/MA, SMK/MAK

\footnotetext{
${ }^{5}$ Ibid., hlm. 11.
} 
b. Melalui semua mata pelajaran, pengembangan diri, dan budaya satuan pendidikan

Pendidikan karekter mensyaratkan bahwa proses pengembangan karakter dilakukan melalui setiap mata pelajaran, dan dalam setiap kegiatan kurikuler, ekstra kurikuler dan kokurikuler. Pengembangan nilai-nilai tersebut melalui keempat jalur pengembangan karakter melalui berbagai mata pelajaran yang telah ditetapkan dalam standar Isi.

c. Nilai tidak diajarkan tapi dikembangkan melalui proses belajar (value is neither cought nor taught, it is learned) Dalam hal ini pendidikan karakter mengandung makna bahwa materi nilainilai karakter bukanlah bahan ajar biasa. Tidak semata-mata dapat ditangkap sendiri atau diajarkan, tetapi lebih jauh diinternalisasi melalui proses belajar. Artinya, nilai-nilai tersebut tidak dijadikan pokok bahasan yang dikemukakan seperti halnya ketika mengajarkan suatu konsep, teori, prosedur, atau pun fakta seperti dalam mata kuliah atau pelajaran agama, bahasa Indonesia, sejarah, matematika, pendidikan jasmani dan kesehatan, seni, ketrampilan, dan sebagainya. Materi pelajaran biasa digunakan sebagai bahan atau media untuk mengembangkan nilai-nilai karakter peserta didik. Oleh karena itu pendidik tidak perlu mengubah pokok bahasan yang sudah ada tetapi menggunakan materi pokok bahasan itu untuk mengembangkan nilai-nilai karakter. Juga, pendidik tidak 
harus mengembangkan proses belajar khusus untuk mengembangkan nilai. Suatu hal yang selalu harus diingat bahwa satu aktivitas belajar dapat digunakan untuk mengembangkan kemampuan dalam ranah kognitif, afektif, dan psikomotor. Konsekuensi dari prinsip ini nilai-nilai karakter tidak ditanyakan dalam ulangan ataupun ujian. Walaupun demikian, peserta didik perlu mengetahui pengertian dari suatu nilai yang sedang mereka tumbuhkan pada diri peserta didik. Peserta didik tidak boleh berada dalam posisi tidak tahu dan tidak paham makna nilai terebut.6

\section{Lembaga Pendidikan Islam Non Formal (Pondok Pesantren)}

Pondok pesantren ditinjau dari bahasa terdiri dari dua kata yang menunjukkan pada suatu pengertian yaitu kata pondok dan kata pesantren. Menu-rut Mujamil Qomar dalam pemakaian sehari-hari, istilah pesantren biasa disebut dengan pondok saja atau kedua kata ini digabung menjadi pondok pesantren. Secara esensial, semua istilah ini mengandung makna yang sama.7

Menurut Kamus Besar Indonesia, pesantren yang dalam bahasa Arab disebut dengan "ma'had" atau pesantren adalah bangunan tempat tinggal bagi kelompok orang untuk sementara waktu yang terdiri atas sejumlah kamar, dan dipimpin oleh seorang kepala ma'had. Sedangkan menurut Dhofier, pesantren

${ }^{6}$ Ibid., hlm. 11-13.

${ }^{7}$ Mujamil Qomar, Pesantren dari transfor-masi metodologi menuju demokratisasi institusi, (Surabaya: Erlangga, 2003), hlm. 1 
berasal dari kata santri yang diimbuhi awalan Pe- dan akhiran an yang berarti menunjukkan tempat para santri. Dalam perkembangan selanjutnya, pesantren adalah lembaga pendidikan dan pengajaran Agama Islam, yang pada umum-nya pendidikan dan pengajaran tersebut ter-implementasikan dengan cara nonklasikal. Di-mana seorang kiai mengajarkan santri berda-sarkan kitab-kitab bahasa arab dari ulama'-ulama' besar sejak abad pertengahan, sedang-kan para santrinya tinggal dalam asrama.8

Pesantren adalah sebuah lembaga yang khas yang ciricirinya tidak dimiliki oleh lembaga yang lain. Sedangkan unsurunsur yang terdapat dalam sistem pendidikan pesantren secara tradisional yang menjadikannya khas adalah kiai, santri, masjid, pondok dan pengajaran kitab-kitab klasik.9 Pendidikan pondok pesantren sendiri merupakan produk pendidikan asli Indonesia, atau dengan istilah Indigenious, dan merupakan lembaga Pendidikan Islam yang tertua di Indonesia.10

Secara garis besar, pesantren bisa dibedakan paling tidak menjadi tiga jenis, yaitu salafiyah (tradisional), khalafiyah (modern) dan terpadu. Salafiyah adalah tipe pesantren yang hanya mengajarkan ilmu-ilmu agama Islam, atau kitab-kiab

8 Dhofier, Z. The pesantren tradition, the role of the kyai in the maintenance of tranition islam in java, (Arizona State University: Program for Southeast Asi-an Studies Uniten Stated of America,1982), hlm. 18.

${ }^{9}$ Zamakhsyari Dhofier, Tradisi Pesantren: Studi tentang Pandangan Hidup Kiyai, (Jakarta: LP3ES, 1981), hlm. 60

10 N. Madjid, Modernisasi pesantren (kritik nurcholis terhadap pendidikan Islam tradisional), (Jakarta: Ciputat Press, 2002), hlm. 5. 
klasik yang ditulis oleh para ulama terdahulu. Metode pengajaran yang digunakan hanyalah metode bandongan, sorogan, hafalan dan musyawarah. Khalafiyah adalah tipe pesantren modern, yang di dalamnya mengajarkan ilmu-ilmu agama Islam dan ilmu-ilmu pengetahuan umum, tetapi masih tetap mengajarkan kitab-kitab klasik seperti pesantren salafiyah. Pola kepemimpinan pesantren tipe ini biasanya kolektifdemokratis, sehingga tugas dan wewenang telah dideskripsikan secara jelas, sehingga tidak ada pemusatan keputusan pada figur seorang kiai. Sistem yang digunakan adalah sistem klasikal, dan evaluasi yang digunakan telah memiliki standar yang jelas dan modern.11

Metode-metode pembelajaran yang bersifat tradisional menjadi trade mark pondok pesantren, yaitu: (1) metode sorogan, (2) metode bandongan/ wetonan, (3) metode musyawarah (bahtsul masa'il), (4) metode pengajian pasanan, (5) metode hafalan (muhafadzah), (6) metode demonstrasi/praktek ibadah, (7) metode rihla-hilmiyah (studitour), (8) metode muhawarah /muhadatsah, (9) metode mudzarakah, (10) metode riyadhah. 12 Sedangkan tentang "Kekuatan karakter santri" Fuad menerangkan bahwa ada 5 karakter yang menonjol pada santri yaitu: (1) Kebersyukuran

${ }^{11}$ Wahjoetomo, Perguruan Tinggi Pesantren, Pendidikan Alternatif Masa Depan, (Jakarta: Gema Insani Press, 1997), hlm. 45. hlm. 73-144.

${ }^{12}$ Dalam Depag, Detpeka-pontren ditjen kelembagaan Agama Islam, 2003, 
(gratitude),(2) Keadilan (fair-ness), (3) Kebaikan hati (kind-ness),

(4) Kewargaan (citizenship), (5) Harapan (hope).13

D. METODE

Metode yang digunakan dalam penelitian ini menggunakan jenis penelitian kualitatif dengan Pendekatan Fenomenologi. Dalam penelitian kualitatif, peneliti sebagai instru-men kunci (key instrument). Kekuatan metode riset terletak pada kemampuan periset me-masuki bidang persepsi orang lain, guna me-mandang kehidupan sebagaimana dilihatnya. Metode penelitian kualitatif fenomenologi, teori dengan sendirinya lahir atau dilahirkan oleh fenomena yang memberitakan dirinya sendiri. Fenomenologi mendeskripsikan peng-alaman, bukan menjelaskan atau menganalis isinya.14

Moustakas menjelaskan tentang bagaimana studi fenomenologi mengorganisir dan menganalisis data, "pengorganisasian data di mulai sejak peneliti mentranskrip wawan-caranya“. Sedangkan Creswell meringkas penjelasan Moustakas menjadi Creating meaning units (pengkreasian unitunit pemaknaan), Clustering themes (pengelompokan te-matema), Advancing textual and structural discriptions

${ }^{13}$ Fuad Nashori, Kekuatan karakter santri. Jurnal Studi Agama Millah, Vol. XI No. 1. (Yogyakarta: Pascasar-jana Universitas Islam Indonesia, 2011), hlm. 208.

${ }^{14}$ Mudjiyanto, B \& Kenda, N. Metode fenomenologi sebagai salah satu metodologi penelitian kualitatfif dalam komunikologi. Jurnal Penelitian Komu-Nikasi Dan Opini Publik, Volume No.11. (Manado: Balai Pengkajian dan Pengembangan Informasi dan Komunikasi Indonesia, 2010), hlm. 1. 
(pengembangan deskripsi tekstual dan structural), And presenting an integration of textual and structural descriptions into an ax-haustive description of essential inva-riant structure (or essence) of the experi-ence (dan pengintegrasian penyajian berbagai deskripsi tekstual dan structural pada kedalaman deskripsi struktur peng-alaman invariant yang esensial).15

\section{E. Pelaksanaan Penanaman Nilai-nilai Karakter di Lembaga Pendidikan Islam}

Salah satu lembaga pendidikan Islam di Kota Semarang yang menerapkan pendidikan karakter melalui kegiatan di luar Kegiatan Belajar mengajar adalah Madrasah Aliyah Riyadlus Sholihin Al Islamy, secara geografis, madrasah ini keberadaannya tidak jauh dari Unnes (Universitas Negeri Semarang) yakni bertempat di Desa Ngijo Kecamatan Gunungpati Kota Semarang. Sebelum Menteri Pendidikan Nasional, pada waktu itu dijabat oleh Mohammad Nuh yang menegaskan, perlunya disusun kurikulum pendidikan karakter, Madrasah ini secara tidak langsung sudah melaksanakan pendidikan karakter, salah satu yang mendorong pendidikan karakter adalah sebagian besar siswa-siswi di madrasah tersebut bertempat di Pondok Pesantren yang sama-sama di bawah satu Yayasan sehingga secara otomatis mereka sudah dibekali dan diajarkan pendidikan karakter, khususnya karakter pesantren

15 Abdulloh Hamid, Penanaman Nilai-Nilai Karakter Siswa SMK Salafiyah Prodi TKJ Kajen Margoyoso Pati Jawa Tengah, Jurnal Pendidikan Vokasi, Vol 3, No. 2, (Jogjakarta: ADGVI, 2013), hlm. 145. 
yang mempengaruhi mereka dalam pelaksanaan KBM di sekolahan.

Karena berbasis pesantren, maka penanaman pendidikan karakter tentunya tidak jauh dari karakter pesantren sendiri. Media yang digunakan pihak madrasah dalam penanaman karakter siswa didiknya yaitu melalui kegiatan pembacaan Rothib al Haddad dilanjutkan dengan sholat Dhuha berjamaah dan tadarus AlQur'an, kegiatan tersebut dilakukan setiap pagi hari, sedangkan untuk siang harinya, dilaksanakan sholah Dhuhur berjama'ah. Untuk kegiataan pagi hari dimulai pada pukul 06.45 - 07.15, setelah itu baru dimulai KBM di kelas masing-masing.

Dengan membiasakan pembacaan Rothib al Haddad, diharapkan siswa-siwi memiliki hati yang tenang dan bersih dari segala dosa sehingga mudah menerima pelajaran dan nasihatnasihat yang baik, karena isi dari Rothib al Haddad adalah bacaan-bacaan dzikir yang bisa menjadikan tenang hatinya bagi yang sering membacanya. Hal ini telah ditegaskan dalam AlQur'an surat Ar-Ra'du ayat 28 sebagaimana berikut :

Artinya: (yaitu) orang-orang yang beriman dan hati mereka manjadi tenteram dengan mengingat Allah. Ingatlah, hanya dengan mengingati Allah-lah hati menjadi tenteram.

Ayat ini merupakan sebuah solusi yang konkrit bagi manusia dalam menjalani kehidupan, agar tidak melakukan 
penyimpangan dan demoralisasi tatanan hidup yang berujung pada suasana yang tidak stabil dalam dirinya, khususnya pada anak-anak ditingkat Aliyah. Dalam kitab Nashaih Al Ibad, Imam Nawawi mengatakan sebagai berikut:

$$
\begin{aligned}
& \text { ملاك و هِئِي لِو أ عاقلِ و ـالله زكذ : صصغلا جزِفت عا }
\end{aligned}
$$

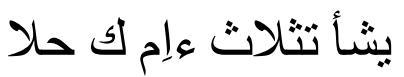

"Tiga perkara yang dapat menghilangkan kegundahan (pikiran stres) yaitu dzikir (mengingat) kepada Allah SWT, silaturahim kepada para wali dan memperhatikan perkataan para Ulama".16

Dzikir merupakan sarana mendekatkan diri kepada Allah sehingga mendapatkan ketenangan dan kedamaian hidup di dunia dan akhirat. Dzikir juga sebagai salah satu media untuk mengembangkan potensi iman yang memberi nilai positif dalam kehidupan.

Sedangkan dengan menjalankan sholat Dhuha berjama'ah, peserta didik diharapkan selain menjadi pribadi yang shalihshalihah, penuh tanggungjawab, patuh dan bisa bekerjasama dalam melakukan kebaikan juga menjadi pribadi yang berkecukupan dalam hal rizki. Tentunya sudah masyhur dikalangan kita tentang dalil-dalil keutamaan sholat Dhuha yang merupakan salah satu wasilah membuka pintu-pintu rizki.

16 Syeikh Nawawi Ibn Umar al jawi, Nashaih al 'Ibad (Nasehat Bagi Sang Hamba), ter. Abu Mujadidul Islam Mafa, (Surabaya: Gita Media Press,2008) hlm. 54 
Selanjutnya tadarus AlQur'an bersama-sama, selain mendapatkan pahala, peserta didik diharapkan menjadi pribadi yang Qur'ani, yakni trampil dalam membaca AlQur'an dan bisa mengaplikasikan isi kandungannya dalam prilaku. Hadits tentang keutamaan membaca AlQuran diantaranya adalah sebagai berikut :

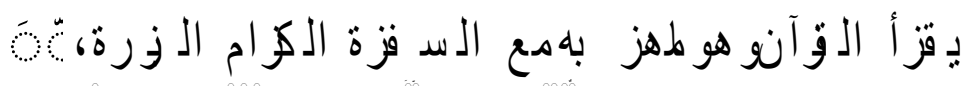

Artinya : Orang yang membaca Al-Qur'an dan dia mahir membacanya, dia bersama para malaikat yang mulia. Sedangkan yang membaca Al-Qur'an namun dia tidak tepat dalam membacanya dan mengalami kesulitan, maka baginya dua pahala." [Al-Bukhari 4937, Muslim 244]

Dari hadits tersebut, bisa bisa dimengerti bahwasannya orang selalu membaca AlQur'an adalah orang yang mulia karena para malaikat bersamanya, itulah salah satu cara pihak MA Riyadlus Sholihin merutinitaskan tadarus AlQur'an pada peserta didik, sehingga mereka menjadi terbiasa yang akhirnya tertanamlah karakter qur'ani pada setiap pribadi peserta didiknya.

\section{F. Kendala yang dihadapi dalam melaksanakan pendidikan karakter di Lembaga Pendidikan Islam}

Membentuk karakter di lembaga pendidikan tidaklah mudah, butuh kerjasama berbagai pihak, tugas pembentukan 
karakter peserta didik di sekolahan bukanlah semata-mata tanggungjawab kepala sekolah, melainkan semua pihak yang berada di lingkungan sekolah, baik pendidik maupun tenaga kependidikan dan juga peranan orang tua atau wali peserta didik. Tentunya dalam pelaksanaannya mengalami beberapa kendala, secara umum kendala tersebut bisa dibagi menjadi dua, yaitu kendala internal dan eksternal.

\section{Kendala Internal}

Kendala internal ini merupakan kendala dari masingmasing pendidik maupun tenaga kependidikan sebagai pemangku dan pengatur kebijakan, khususnya pada pendidik atau guru, karena seorang guru merupakan model bagi seluruh peserta didiknya. Menurut pepatah jawa, guru merupakan akronim dari "digugu lan ditiru" (dipercara dan dicontoh), oleh karenanya guru harus bisa menjadi tokoh teladan yang baik baik bagi peserta didiknya.

Bagi guru yang tidak bisa menjadi panutan peserta didiknya, maka menjadi tanggung jawab kepala sekolah untuk menegur dan memperingatkannya baik secara langsung maupun dalam rapat evaluasi bulanan sekolah.

\section{Kendala Eksternal}

Kendala eksternal merupakan kendala yang datannya dari peserta didik, untuk mengatasi kendala ini akan menjadi lebih mudah setelah kendala internal teratasi, karena peserta didik merupakan obyek dari pelaksanaan pendidikan karakter sendiri, dengan melalui model reward dan 
punishment. Dengan adanya reward, diharapkan peserta didik bisa lebih termotifasi untuk menjalankan segala aktifitas yang telah ditentukan pihak sekolah dalam pembentukan karakter, misalkan setiap satu bulan sekali, kepala sekolah memberi hadiah kepada tiga peserta didiknya yang terajin, hadiah bisa berupa uang atau hal-hal lain yang bisa memacu semangat peserta didik lainnya.

Tidak hanya reward, punishment juga menjadi penting sebagai salah satu penentu suksesnya pendidikan karakter di lembaga pendidikan, karena dengan adanya punishment, diharapkan membuat jera bagi peserta didik yang melanggar peraturan. Punishment yang baik harusnya tidak berupa kekerasan fisik, tetapi tindakan yang bisa menjadikan peserta didik sadar dan menyesal bahwa melanggar peraturan sekolah merupakan tindakan yang tidak terpuji sehingga peserta didik dengan kesadaran diri tidak akan mengulanginya lagi. Sekedar contoh, disuruh membaca al Qur'an satu juz di halaman sekolah, menulis ayat al Qur'an yang telah ditentukan, membaca istighfar dan lain sebagainya.

Dalam mengatasi pelanggaran peserta didik, selain usaha lahir, para pendidik harusnya melakukan usaha yang sifatnya batiniyah, yaitu melalui do'a-do'a yang dipanjatkan setiap selesai sholat, supaya peserta didiknya diberi pertolongan dan dimudahkan oleh Allah SWT dalam segala urusan dan perkara yang berkaitan dengan kebikan. 


\section{G. Simpulan}

Pendidikan karakter di lembaga pendidikan harusnya menyesuaikan dengan visi dan misi dari lembaga itu sendiri, karena menjadi ciri khas tersendiri dari lembaga tersebut. Maka tidaklah heran, bila pendidikan karakter di lembaga pendidikan satu bisa berbeda dengan lembaga pendidikan yang lain.

Berhasil dan tidaknya pendidikan karakter di lembaga pendidikan bukan semata-mata tanggungjawab dari kepala sekolah, melainkan tanggung jawab bersama, perlu kerjasama yang baik antara pendidik, tenaga kependidikan, lingkungan sekolah maupun orang tua atau wali juga komite sekolah dan stakeholder yang ada. Sekolahan merupakan wadah membina pendidikan karakter peserta didik, sedangkang lingkungan masyarakat dan keluarga menjadi ajang pengaplikasikan pendidikan karakter yang telah ditanamkan di lembaga pendidikan. Berkat kerjasama yang baik dari berbagai pihak, tidaklah mustahil pendidikan karakter akan benar-benar terwujud. 


\section{DAFTAR PUSTAKA}

Al Jawi, Syeikh Nawawi Ibn Umar. 2008. Nashaih al Ibad (Nasehat Bagi Sang Hamba), ter. Abu Mujadidul Islam Mafa. Surabaya: Gita Media Press.

Asmani, Jamal Ma'mur. 2010. Buku Panduan Internalisasi Pendidikan Karakter di Sekolah. Jakarta: Grasindo.

Depag. 2003. Detpeka-pontren ditjen kelembagaan Agama Islam.

Dhofier, Z. 1982. The Pesantren Tradition, The Role Of The Kyai in The Maintenance of Tranition Islam in Java. Arizona State University: Program for Southeast Asi-an Studies Uniten Stated of America.

Dhofier, Zamakhsyari. 1981. Tradisi Pesantren: Studi tentang Pandangan Hidup Kiyai. Jakarta: LP3ES.

Hamid, Abdulloh. 2013. Penanaman Nilai-Nilai Karakter Siswa SMK Salafiyah Prodi TKJ Kajen Margoyoso Pati Jawa Tengah, Jurnal Pendidikan Vokasi, Vol 3, No. 2. Jogjakarta: ADGVI.

Kemendiknas. 2010. Bahan Pelatihan Pengembangan Pendidikan Budaya dan Karakter Bangsa. Jakarta: Badan Penelitian dan Pengembangan Pusat Kurikulum.

Kemendiknas. 2011. Desain Induk Pendidikan Karakter. Jakarta: Puskur.

Madjid, N. 2002. Modernisasi Pesantren ( Kritik Nurcholis Terhadap Pendidikan Islam Tradisional ). Jakarta: Ciputat Press.

Mudjiyanto, B \& Kenda, N. 2010. Metode fenomenologi sebagai salah satu metodologi penelitian kualitatfif dalam komunikologi. Jurnal Penelitian Komu-Nikasi Dan Opini Publik, Volume No.11. Manado: Balai Pengkajian dan Pengembangan Informasi dan Komunikasi Indonesia 
Nashori, Fuad. 2011. Kekuatan Karakter Santri. Jurnal Studi Agama Millah, Vol. XI No. 1. Yogyakarta: Pascasar-jana Universitas Islam Indonesia.

Qomar, Mujamil. 2003. Pesantren dari Transformasi Metodologi Menuju Demokratisasi Institusi. Surabaya: Erlangga.

Wahjoetomo. 1997. Perguruan Tinggi Pesantren, Pendidikan Alternatif Masa Depan. Jakarta: Gema Insani Press. 